\title{
THE USE OF PROJECT MANAGEMENT METHODOLOGIES AND PROJECT RISK MANAGEMENT IN THE LIGHT OF EMPIRICAL RESEARCH
}

\author{
WYKORZYSTANIE METODYK ZARZADZANIA PROJEKTAMI I ZARZADZANIE \\ RYZYKIEM PROJEKTU W ŚWIETLE BADAŃ EMPIRYCZNYCH
}

https://doi.org/10.34739/zn.2020.54.02

Maciej Brzozowski

${ }^{1}$ Poland, Poznań University of Economics and Business, Institute of Management m.brzozowski@ue.poznan.pl; ORCID: 0000-0002-9651-2611

\begin{abstract}
The main purpose of the paper is to examine, on the basis of empirical research, the perceived manner of project management in organizations, as well as to determine the frequency of application of selected project management methodologies, in addition to the assessment of their usefulness for project risk management. The first part of the paper presents - identified on the basis of literature studies - types and examples of project management methodologies along with basic assumptions of the project risk management process, and in the second part - the results of empirical research conducted by recourse to a questionnaire among the participants of projects implemented in various types of organizations. The study showed that in organizations employing respondents, the methodical manner of project management is most often used, while the most popular project management methodologies were PMBoK, Agile and PRINCE2, wherein respondents highly rated the usefulness of selected methodologies for effective project risk management.
\end{abstract}

Keywords: project management, project risk management, project management methodology

\begin{abstract}
Streszczenie: Podstawowym celem artykułu jest zbadanie na podstawie przeprowadzonych badań empirycznych postrzeganego sposobu zarządzania projektami w organizacjach, jak również określenie częstotliwości stosowania wybranych metodyk zarządzania projektami wraz z oceną ich przydatności w procesie zarządzania ryzykiem projektu. W pierwszej części artykułu przedstawiono - zidentyfikowane na podstawie studiów literaturowych - rodzaje i przykłady metodyk zarządzania projektami, jak również podstawowe założenia procesu zarządzania ryzykiem projektu, a w drugiej części - wyniki badań empirycznych przeprowadzonych z wykorzystaniem kwestionariusza ankiety wśród uczestników projektów realizowanych w organizacjach różnego typu. Badanie wykazało, że w organizacjach zatrudniających ankietowanych najczęściej stosowany jest częściowo metodyczny sposób zarządzania projektami, natomiast najpopularniejszymi metodykami zarządzania projektami były PMBOK, Agile oraz PRINCE2, przy czym respondenci wysoko ocenili przydatność stosowanych metodyk w procesie zarządzania ryzykiem projektu.
\end{abstract}

Słowa kluczowe: zarządzanie projektami, zarządzanie ryzykiem projektu, metodyka zarządzania projektami

\section{Introduction}

Project management as an area of knowledge has been developed primarily in response to the needs of business practice, to provide support in efficient execution of an increasing number of various projects. In just the last few decades, project management has transformed from a set of simple rules and tools to a comprehensive and multifaceted sub-discipline of management sciences, with its own scope of research, research approaches, terminology, and theoretical and methodological foundations (Trocki \& Bukłaha, 2016). The tangible effect of this development is the variety of methodological support for project management in the form of numerous methodologies, standards and techniques (Jovanović \& Berić, 2018). The multitude of methodologies facilitates the selection of appropriate instruments to the specificity of projects, but also requires a high awareness on the part of managers, coupled with their ability to make proper choices within a wide range of suggested methodological solutions. Therefore, it seems 
reasonable to ask - to what extent do employees involved in projects use the available project management methodologies?

Risk management is commonly described as a key factor in successful project management. Project risk - according to the definition of the Project Management Institute - is an uncertain incident or circumstance which, if occurred, may have a good or bad impact on some of the project's aims such as: time, cost, scope or quality (PMBOK, 2017). Risk management however, is a certain type of action undertaken to counteract and reduce some uncertainty in a project, which aims at identifying all the predictable risk factors, evaluating its likelihood of occurrence and the level of harmfulness. Consequently, risk management outlines and implements the suitable tools to response to the risk (Masar et al., 2019).

The main goal of the study is to investigate the perceived approach to project management in organizations based on empirical research, as well as to determine the frequency of the application of selected project management methodologies, along with an assessment of their usefulness for effective project risk management. The implementation of this goal was carried out through a critical review of selected scientific publications on project management methodologies and project risk management, followed by identification, classification and explication of the phenomena studied, and finally, their empirical verification on a group of employees of Polish enterprises professionally involved in the implementation of projects.

\section{Literature review}

Project management methodologies can be defined as sets of methods, techniques, procedures and best practices, setting out the course of action that leads to successful project implementation. They are commonly based on a specific project management approach, that defines a set of principles and guidelines which determine the manner in which projects are managed (Spundak, 2014). Project management methodologies offer in an orderly manner knowledge that has been recognized by the scientific community and/or practitioners as a recommended practice. Numerous authors (Chin et al., 2012; Głodziński \& Marciniak, 2018; Joslin \& Muller, 2015; Wells, 2012) agree that an efficient project management is not possible without an appropriate methodology.

Depending on the area of their application, the following groups of project management methodologies can be distinguished (Trocki, 2017):

- universal project management methodologies - offering the widest scope of use in various areas and situations of project management, usually prepared as standards by organizations dealing with the creation and popularization of project management patterns;

- industry project management methodologies developed by professional institutions of specific industries and adapted to the specificity of projects implemented in a given sector of the economy;

- problem-based project management methodologies - referring to the problemspecific (e.g. related to project risk or competences of project participants) complexes of project management tasks;

- corporate project management methodologies - developed (often as an adaptation of universal or industry methodologies) and used by large organizations with extensive experience in project implementation;

- personal project management methodologies - published in the form of textbooks and monographs, and constituting a synthesis of the knowledge and professional experience of their authors.

An alternative classification of project management methodologies presented by Grau (2013) includes: de facto standards (universal applications), special standards (project type oriented), de jure standards (certificated), and project maturity models (PBO oriented).

The selection and adaptation of the appropriate project management methodology to the specificity of a given organization and its project activity is a complex issue, closely related, on the one hand, to the attributes of individual methodologies, and, on the other hand, dependent on the conditions of the organization itself and the individual preferences of people involved in the implementation of projects (Jovanović \& Bircić, 2018; Spundak 2014).

The subject of this study is selected universal project management methodologies. The chosen examples of this type of methodology include the following standards - PMI (PMBOK, 2017), PRINCE2 (OGC, 2009), IPMA (2015), TenStep (TenStep Project Management Process, 2014), Agile with Scrum (Schwaber \& Sutherland, 2013).

Risk is designated as an imminent attribute of business projects and there are a number of features of a project which inevitably introduce risk (Buganova \& Simickova, 2019; Hilson, 2009; Popescu et al., 2009): 
- uniqueness - every project, to some extent, is unique, comparing to the previous projects, the new one contains some elements which generate a new source of uncertainty;

- complexity - projects are, by its definition, said to be complex entities; its complexity may emerge at various levels (such as: technical, personal or commercial ones) which not only determine some certain type of actions, but also generate numerous relations within them - one of the essential source of uncertainty in project management;

- relying on assumptions and limitations defining a project's scope means accepting certain assumptions which concern some future events and setting limitations, within which the expected events should occur; both the assumptions and the identified limitations might turn out to be wrong and become a source of risk in a project;

- performed by people - the behavior of the project members are, to some extent, unpredictable, which introduce some sort of uncertainty to the project management;

- different interests of stakeholders - the project's stakeholders' attitude evolves as the project's being implemented, as well as their expectations and possible forms of interactions to a project (both positive and negative ones), which raises the scope of uncertainty as well;

- generating changes - projects are often called to be change agents, which carry from the current organizational state to the desirable one in the future. The process of change itself becomes a crucial source of uncertainty as well (resistance to the changes is an inevitable part of it);

- being under influence of the environment projects are not implemented in a vacuum, but are affected by many external factors - which are the sources of both challenges and limitations; the environment contains not only intra-organizational context of the project realization but also factors outside the organization (general environment and competitive environment factors).

As a consequence of the mentioned features, project risk factors, like the other component parts of a project (assignments, resources, people) are, by definition itself, limited (because all the projects are being carried out within frameworks, such as time limitations, resource availability, agreed aims or action plans) and are subject to management during the process of project management as well as mutually dependable (which is the consequence of the project's complexity).
Project risk management is established as a scientific field and provides important contributions in supporting decision-making in practice (Aven, 2016). There can be found numerous alternative concepts on project risk management procedure in the literature (Rodrigues-da-Silva \& Crispim, 2014). Their authors identify various number of stages (from 4 to 9) and nomenclature (Chapman, 1997; Gosnik, 2011; Hilson, 2009; Kerzner, 2017; Kliem \& Ludin, 1997; PMBoK, 2017; Raz \& Michael, 2001). Cross-sectional analysis of the compiled research enables to formulate a couple of comments.

Firstly, there has been a certain range of terms reported by most of the authors that should be fulfilled in order to perform project risk management, such as (Kerzner, 2017):

- no stage of the process should be omitted,

- performing all the process stages in the right sequence,

- arranging the whole process,

- process repeatability and continuity,

- starting the process at an early stage of the project.

Secondly, reported authors paid the most attention to the risk identification and analysis. It is undoubtedly the most thoroughly examined and methodically described element in the process of project risk management.

Thirdly, it is difficult to find in the literature some guidelines concerning the process of project portfolio risk management (it has been usually concentrated on a single project). It has been mentioned the need to carry out such a process, but even if that subject is being brought up (i.e. in PMl's standard), there is a shortage of hints on how it ought to be implemented. Among the issues that should be raised, there should be pointed out the question of standardizing the process of risk management for projects carried out simultaneously (including the impact of risk factors of one project on other projects), a question of risk connected with lack of balance in a portfolio of projects, and finally the question of risk concerning the adaptation of organizational resources to the portfolio of projects that are carried out (Sanchez et al., 2008).

Fourthly, in the majority of opinions mentioned above, authors don't see any need to sum up the process by the final evaluation of the risk management after the project has been accomplished. That said, evaluation allows for an assessment of the actions taken on the other stages and consequently improved risk management in the following projects. This issue of the successful procedure was exemplified by Hilson (2009). 
Fifthly, in most of the proposed procedures there is a lack of a separated implementation stage of reaction to risk (i.e. it is not present in PMI standard). It may cause that the reaction to the evaluated risk will not be proper enough; it will lack the determination and knowledge to implement it in practice. The authors, whose procedures don't include the implementation stage probably assume that the proposed reactions to risk will be implemented as a part of a general project management process (Hilson, 2009).

The lack of serious reflections on the matter of reaction to risk brings us to the sixth conclusion; in the majority of the available literature on that issue there are no guidelines as to how risk management roles, tasks and responsibilities should be identified and divided among project team members.

\section{Methodology}

In order to achieve the research goal, three areas of empirical research have been identified: (1) determining the perceived way of project management in the organization, (2) identifying the types of project management methodologies used, (3) assessing the suitability of the applied project management methodologies for effective project risk management. Measurement of the analyzed phenomena was carried out taking into account the differences due to the financial sector. The source of the evaluation are the results of empirical research carried out with the use of the survey questionnaire in 2016-2018. The scope of empirical research included people declaring professional involvement in projects (subjective scope of the study), conditions related to project management in organizations (factual scope of the study), Wielkopolskie Voivodeship in Poland (territorial research scope) and the years 20162018 (temporal scope of research). The size of the research sample was 384 observations, while the selection of the sample was deliberate - the selection criterion was the respondent's declaration regarding professional work in projects. The structure of the research sample is presented in Figure 1.
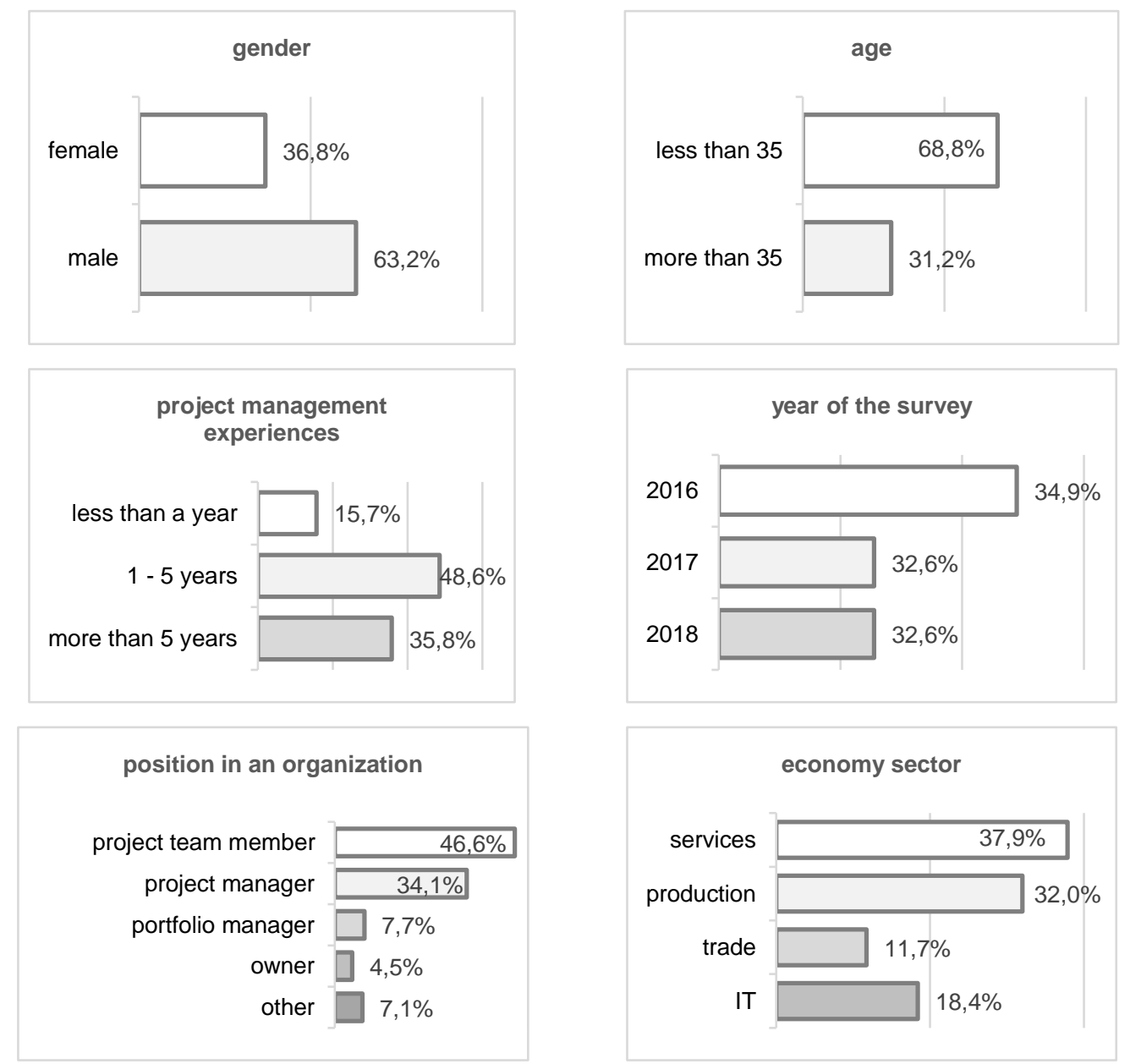

Figure 1. Demographic characteristics of the research sample Source: own calculation on the basis of research results. 


\section{Results and discussion}

The first area of research is to identify the perceived way of managing projects in the organization.

The results presented in Figure 2 allow for a ranking of project management approaches in the surveyed organizations in accordance with the frequency of their application. According to the declarations of respondents, the partially methodical way of project management is most often used $(35.2 \%$ of indications in total) - it should be noted that the frequency of using this approach to project management increases from less than $31 \%$ in 2016 to over $38 \%$ in 2018 . Subsequently, a methodical, but diversified manner of project management $(24.7 \%$ of indications in total) and an accidental approach (23.4\% of indications in total) were indicated. The comprehensive approach to project management in the organization was indicated as the least popular ( $16.7 \%$ of responses in total).

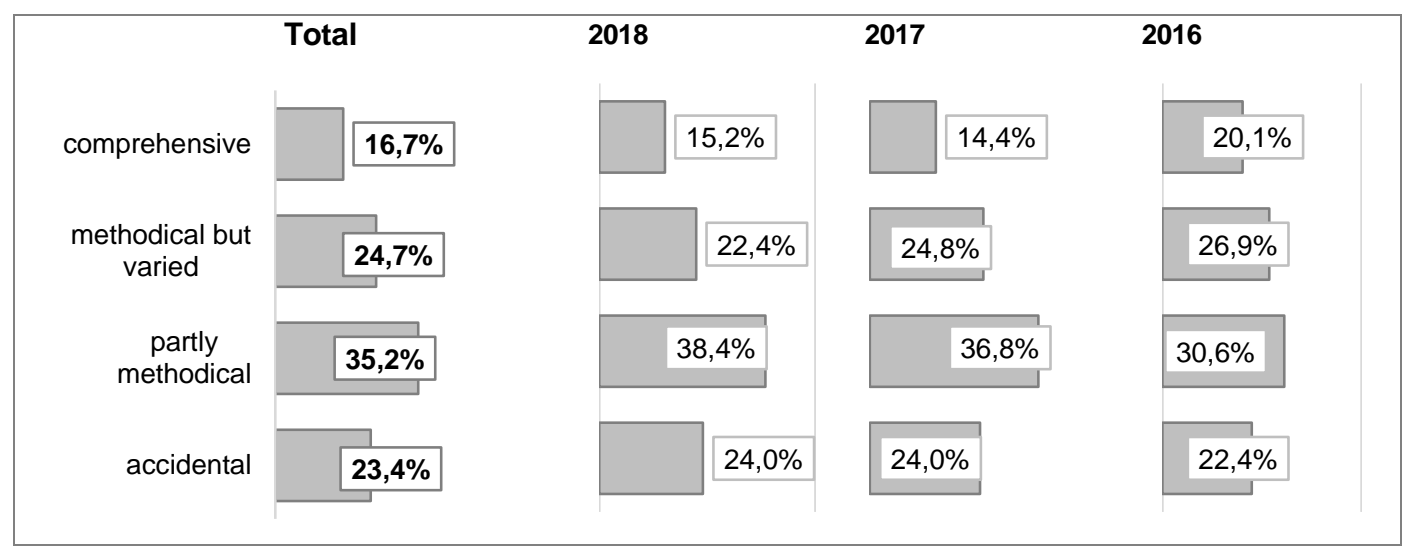

Figure 2. The manner of project management in the organization Source: own calculation on the basis of research results.

Differences in the analyzed area can also be observed in terms of the sector of activity of the surveyed organizations (Table 1). The analysis of the obtained results clearly indicates the IT sector as the one in which the use of project management methodologies in the organization occurs most often - over $27 \%$ of respondents declared the use of a comprehensive approach, over $30 \%$ of a differentiated methodological approach, and less than $41 \%$ of a partially methodical approach. This means that in only slightly more than $1 \%$ of the surveyed organizations from the IT sector, the respondents declared that they did not use any project management methodology. The sectors where the application of methodological methods of project management is the least frequent are trade and services (respectively over $36 \%$ and over $32 \%$ of indications for the random method of project management). On the other hand, in the production sector, the frequency of applied methodological methods of project management should be assessed as average.

Table 1. Ways of managing projects in the organization in terms of the sector of the organization's operation

\begin{tabular}{|c|c|c|c|c|}
\hline Ways of managing projects in the organization & Services & Production & Trade & It \\
\hline accidental (no use of the methodology) & $32,4 \%$ & $20,0 \%$ & $36,4 \%$ & $1,4 \%$ \\
\hline $\begin{array}{l}\text { partially methodical (elements of project management } \\
\text { methodology are used) }\end{array}$ & $26,8 \%$ & $42,5 \%$ & $31,8 \%$ & $40,6 \%$ \\
\hline $\begin{array}{l}\text { methodical, but varied (individual projects are managed } \\
\text { in an orderly manner, consistent with the methodology, } \\
\text { however, the methodologies used differ for individual } \\
\text { projects) }\end{array}$ & $23,2 \%$ & $25,0 \%$ & $20,5 \%$ & $30,4 \%$ \\
\hline $\begin{array}{l}\text { comprehensive (common methodology for most } \\
\text { implemented projects) }\end{array}$ & $17,6 \%$ & $12,5 \%$ & $11,4 \%$ & $27,5 \%$ \\
\hline
\end{tabular}

Source: own calculation on the basis of research results. 
The second area of the research procedure concerned the identification of examples of project management methodologies used in the organizations employing the respondents. The results presented in Figure 3 indicate a clear dominance of three methodologies - PMBOK (36.4\% of indications), Agile (36\% of indications) and PRINCE2 (35\% of indications).

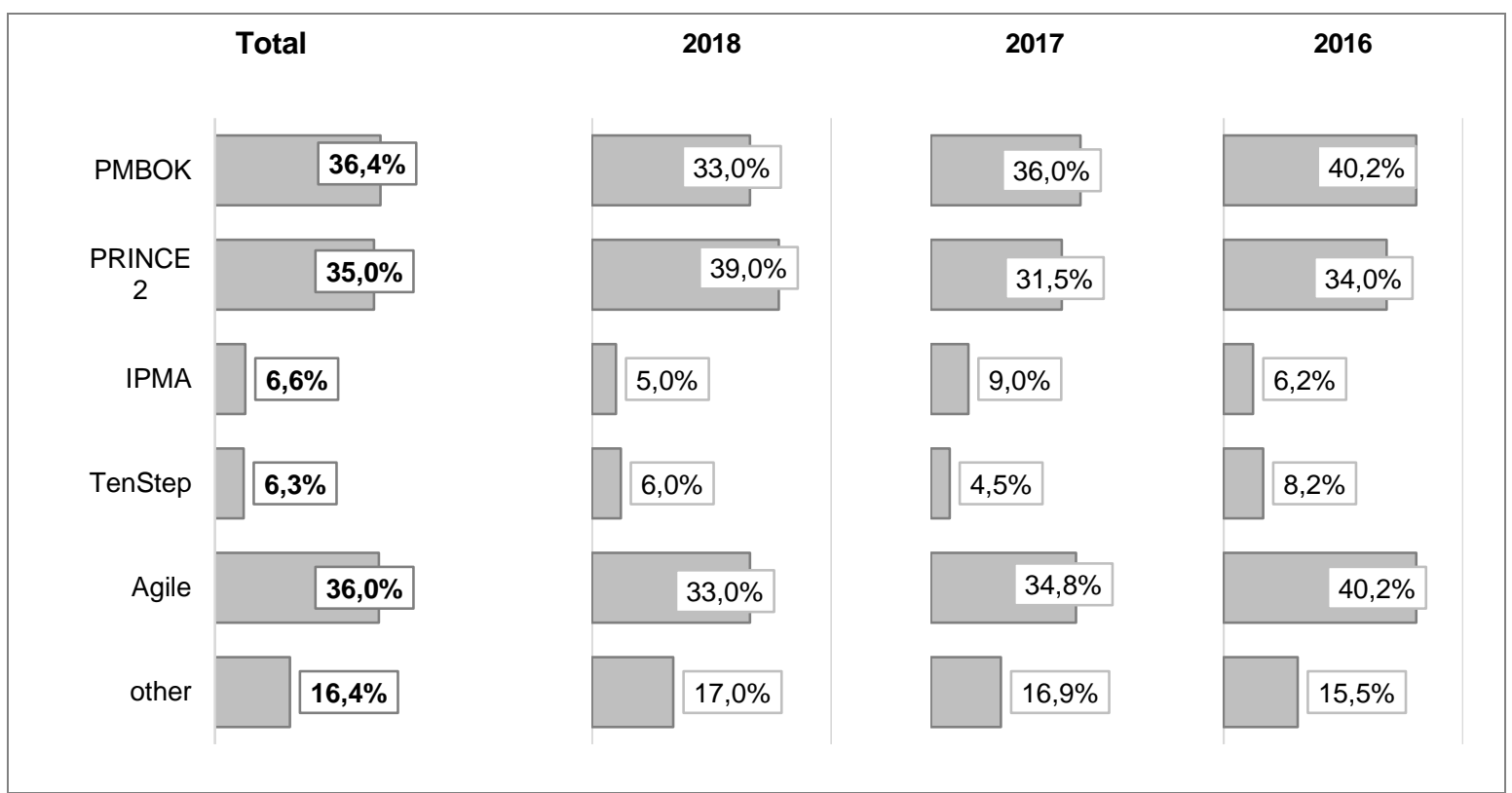

Figure 3. Examples of project management methodologies used in the organization Source: own calculation on the basis of research results.

In the analyzed area, differences can be observed depending on the sector of activity of the surveyed organizations (Table 2). In the IT sector, there was a clear supremacy ( $81.2 \%$ of responses) of agile methodologies traditionally associated with this sector of the economy. The most popular project management methodology in manufacturing and commercial enterprises turned out to be the PMBoK methodology $(48.4 \%$ and $34.6 \%$ of responses, respectively), while PRINCE2 was indicated as the most frequently used project management methodology in service enterprises (41.3\% of responses).

Table 2. Examples of project management methodologies used in the organization according to the sector of the organization's operation

\begin{tabular}{lcccc}
\hline Methodology & Services & Production & Trade & It \\
\hline PMBoK & $33,7 \%$ & $48,4 \%$ & $34,6 \%$ & $26,1 \%$ \\
PRINCE2 & $41,3 \%$ & $33,0 \%$ & $30,8 \%$ & $29,0 \%$ \\
IPMA & $4,3 \%$ & $2,2 \%$ & $11,5 \%$ & $11,6 \%$ \\
TenStep & $7,6 \%$ & $9,9 \%$ & $7,7 \%$ & $0,0 \%$ \\
Agile / Scrum & $30,4 \%$ & $15,4 \%$ & $11,5 \%$ & $81,2 \%$ \\
other & $14,1 \%$ & $27,5 \%$ & $19,2 \%$ & $5,8 \%$ \\
\hline
\end{tabular}

Source: own calculation on the basis of research results.

The final area of the research procedure concerned the assessment of the usefulness of project management methodologies in the project risk management process (Fig. 4). The highest average values were recorded for Agile methodologies $(M=3.34)$ and PMBOK $(M=3.08)$, which on the one hand confirms the growing popularity of agile methodologies observed over the last 20 years and the still high rating of traditional methodologies (e.g. PMBOK). Nevertheless, attention should be paid to the relatively stable assessment of the usefulness of 
agile methodologies in 2016-2018 and the decreasing assessment of the usefulness of traditional methodologies, especially PMBOK (from $M=3.49$ in 2016 to $M=3.10$ in 2018) and TenStep (from $M=3.16$ in 2016 to $M=2.91$ in
2018). The assessment of the usefulness of the other project management methodologies (PRINCE2 and IPMA) in the project risk management process is relatively stable (on average 3.00 ).

\begin{tabular}{|c|c|c|c|c|c|}
\hline & Total & 2018 & 2017 & 2016 & 16 \\
\hline PMBOK & 3,30 & 3,10 & 3,31 & 3,49 & 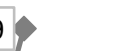 \\
\hline PRINCE2 & 3,08 & 3,05 & 3,12 & 3,06 & \\
\hline IPMA & 3,00 & 2,97 & 3,05 & 2,99 & \\
\hline TenStep & 3,00 & 2,91 & 2,90 & 3,16 & \\
\hline Agile & 3,34 & 3,29 & 3,29 & 3,45 & \\
\hline other & 3,07 & 3,10 & 3,05 & 3,06 & \\
\hline
\end{tabular}

Figure 4. Assessment of the usefulness of project management methodologies in the project risk management process Source: own calculation on the basis of research results.

The research results indicated that the assessment of the usefulness of project management methodologies in the process of project risk management is different in terms of the sector of the organization's operation (Table 3 ). In the service sector, the most useful project management methodology is PMBOK $(\mathrm{M}=3.46)$, in the manufacturing sector also the $\mathrm{PMI}$ methodology $(M=3.28)$, in the commercial sector the PMl methodology $(\mathrm{M}=3.25)$ and Agile $(M=3.27)$, while in the IT sector it is decidedly agile methodologies ( $M=4.22)$.

Table 3. Assessment of the usefulness of project management methodologies in terms of the sector of the organization's operation

\begin{tabular}{lcccc}
\hline Methodology & Services & Production & Trade & It \\
\hline PMBOK & 3,46 & 3,28 & 3,25 & 3,03 \\
PRINCE2 & 3,21 & 3,18 & 3,07 & 2,52 \\
IPMA & 3,07 & 3,06 & 3,07 & 2,67 \\
TEN STEP & 3,11 & 3,03 & 3,07 & 2,67 \\
Agile / Scrum & 3,25 & 2,99 & 3,27 & 4,22 \\
other & 3,06 & 3,17 & 3,02 & 2,97 \\
\hline
\end{tabular}

Source: own calculation on the basis of research results. 


\section{Conclusions}

The following statements should be mentioned as being among the most important conclusions from the conducted empirical research:

- in the organizations employing the respondents, the partially methodical method of project management is most often used, with the IT sector indicated as the one in which the use of project management methodologies in the organization occurs most often;

- respondents' declarations indicate that the three most popular project management methodologies in their employing organizations are, in turn, PMBOK, Agile and PRINCE2, whereby the dominance of selected methodologies for individual sectors, i.e. agile methodologies in the IT sector, PMBOK in the manufacturing and commercial sectors, and finally PRINCE2 in the service sector;

- respondents rated relatively high usefulness of the project management methodologies for effective project risk management, with the highest average scores recorded for Agile and PMBOK methodologies.

It should be emphasized that a broader interpretation of the presented research results is limited due to the lack of representativeness of the research sample used. Possible directions for further research include an analysis of the process of selecting project management methodology in organizations, as well as an analysis of the relationship between the characteristics - both of the organization and project participants. Whereas the effectiveness of risk management in projects of various types, should be considered particularly interesting.

\section{References}

Aven, T. (2016). Risk assessment and risk management: Review of recent advances on their foundation. European Journal of Operational Research, 253(1), 1-13. DOI: 10.32918/nrs. 2019.2(82).01.

Buganova, K., Simickova, J. (2019). Risk management in traditional and agile project management. Transportation Research Procedia, 40, 986-993. DOI: 10.1016/j.trpro. 2019.07.138.

Chapman, C., Ward, P. (1997). Project risk management-process, techniques and insights. Chichester: Wiley.

Chin, C.M., Spowage, A.C., Yap E.H. (2012). Project Management Methodologies: A Comparative Analysis. Journal for the Advancement of
Performance Information and Value, 4(1), 106-118. DOI: 10.37265/japiv.v4i1.102

Głodziński, E., Marciniak, S. (2018). Between Practice and Academic Study: Competitiveness and Complementary Character of Project Management Research. Przedsiębiorczość i Zarządzanie, XIX (6)(2): 149-163.

Gosnik, D. (2011). Extended Model for Managing Risk in New Product Development Projects. Managing Global Transitions: International Research Journal (9)(1), 15-37.

Grau, N. (2013). Standards and excellence in project management - in who do we trust? Procedia Social and Behavioral Sciences, (74), 10-20. DOI: 10.1016/j.sbspro.2013.03.005

Hilson, D. (2009). Managing Risk in Projects. Abingdon: Ashgate Publishing Group.

IPMA (2015). IPMA Competence baseline, version 4.0. International Project Management Association. Switzerland.

Joslin, R., Muller, R. (2015). Relationships between a project management methodology and project success in different project governance contexts. International Journal of Project Management, (33), 1377-1392. DOI: 10.1016/j.jproman. 2015.03.005.

Jovanović, P., Bercić, I. (2018). Analysis of the Available Project Management Methodologies. Management: Journal of Sustainable Business and Management Solutions in Emerging Economies, 23 (3), 3-13. DOI: 10.7595/management.fon.2018.0027.

Kerzner, H. (2017). Project Management: A Systems Approach to Planning, Scheduling and Controlling, 12th Ed. Chichester: Wiley.

Kliem, R., Ludin, I. (1997). Reducing Project Risk. Hampshire: Gower Publishing Limited.

Masar, M., Hudakova, M., Simak, L., Brezina, D. (2019). The current state of project risk management in the transport sector. Transportation Research Procedia, (40), 1119-1126. DOI: 10.1016/j.trpro.2019.07.156

OGC. (2009). Managing Successful Project with PRINCE2. Norwich: Office of Government Commerce.

PMBOK. (2017). A Guide to the Project Management Body of Knowledge. 6th edition. Project Management Institute.

Popescu, G., Gherghinescu, P., lonete, E. (2009). The Basic Framework of Project Risk Management. Progress in Cryogenics and Isotopes Separation, Vol. 12.

Raz, T., Michael, E. (2001). Use and benefits of tools for project risk management. International Journal of Project Management, 19 (1), 9-17. DOI: 10.1016/S0263-7863(99)00036-8. 
Rodrigues-da-Silva, L., Crispim, J. (2014). The project risk management process, a preliminary study. Procedia Technology, (16), 943-949. DOI: 10.1016/j.protcy.2014.10.047.

Sanchez, H., Robert, B., Pellerin, R. (2008). A project portfolio risk - Opportunity identification framework. Project Management Journal, 39(3), 97-109. DOI: 10.1002/pmj.20072.

Spundak, M. (2014). Mixed agile/traditional project management methodology - reality or illusion? Procedia - Social and Behavioral Sciences, (119), 939-948. DOI: 10.1016/j.sbspro.2014. 03.105.

TenStep Inc. (2014). TenStep Project Management Process v13.0, June.

Trocki, M. (Ed.). (2017). Metodyki i standardy zarządzania projektami. [Project management methodologies and standards]. Warszawa: Polskie Wydawnictwo Ekonomiczne.

Trocki, M., Bukłaha, E. (eds.) (2016). Project Management - Challenges and Research Results. Warsaw: Warsaw School of Economics Press.

Wells, H. (2012). How effective are project management methodologies? An explorative evaluation of their benefits in practice. Project Management Journal 43 (6), 43-58. DOI: 10.1002/pmj.21302. 